\title{
Lycopene protects human SH-SY5Y neuroblastoma cells against hydrogen peroxide-induced death via inhibition of oxidative stress and mitochondria-associated apoptotic pathways
}

\author{
CHUNSHENG FENG ${ }^{1}$, TIANFEI LUO ${ }^{2}$, SHUYAN ZHANG ${ }^{3}, \mathrm{KAI} \mathrm{LIU}^{3}$, \\ YANHONG ZHANG ${ }^{4}$, YINAN LUO ${ }^{3}$ and PENGFEI GE ${ }^{3}$ \\ Departments of ${ }^{1}$ Anesthesiology, ${ }^{2}$ Neurology and ${ }^{3}$ Neurosurgery, First Hospital of Jilin University; \\ ${ }^{4}$ Department of Emergent Medicine, People's Hospital of Jilin Province, Changchun, Jilin 130021, P.R. China
}

Received May 11, 2015; Accepted March 14, 2016

DOI: $10.3892 / \mathrm{mmr} .2016 .5056$

\begin{abstract}
Oxidative stress, which is characterized by excessive production of reactive oxygen species (ROS), is a common pathway that results in neuronal injury or death due to various types of pathological stress. Although lycopene has been identified as a potent antioxidant, its effect on hydrogen peroxide $\left(\mathrm{H}_{2} \mathrm{O}_{2}\right)$-induced neuronal damage remains unclear. In the present study, pretreatment with lycopene was observed to protect $\mathrm{SH}-\mathrm{SY} 5 \mathrm{Y}$ neuroblastoma cells against $\mathrm{H}_{2} \mathrm{O}_{2}$-induced death via inhibition of apoptosis resulting from activation of caspase- 3 and translocation of apoptosis inducing factor (AIF) to the nucleus. Furthermore, the over-produced ROS, as well as the reduced activities of anti-oxidative enzymes, superoxide dismutase and catalase, were demonstrated to be alleviated by lycopene. Additionally, lycopene counteracted $\mathrm{H}_{2} \mathrm{O}_{2}$-induced mitochondrial dysfunction, which was evidenced by suppression of mitochondrial permeability transition pore opening, attenuation of the decline of the mitochondrial membrane potential, and inhibition of the increase of Bax and decrease of Bcl-2 levels within the mitochondria. The release of cytochrome $c$ and AIF from the mitochondria was also reduced. These results indicate that lycopene is a potent neuroprotectant against apoptosis, oxidative stress and mitochondrial dysfunction, and could be administered to prevent neuronal injury or death.
\end{abstract}

\section{Introduction}

Oxidative stress is important in mediating brain injury caused by different pathological conditions, such as cerebral

Correspondence to: Professor Pengfei Ge, Department of Neurosurgery, First Hospital of Jilin University, 71 Xinmin Street, Changchun, Jilin 130021, P.R. China

E-mail: gepf@jlu.edu.cn; pengfeige@gmail.com

Key words: lycopene, apoptosis, oxidative stress, mitochondria, cytochrome $c$, apoptosis inducing factor ischemia/reperfusion, head trauma, epilepsy and neurodegenerative diseases (1-4). A previous study demonstrated that neurons, glial cells, and cerebral microvasculature could be damaged during the process of oxidative stress (5). The crucial feature of oxidative stress is excessive production of reactive oxygen species (ROS), such as superoxide anions $\left(\mathrm{O}_{2}{ }^{-}\right)$, hydroxyl radicals and hydrogen peroxide $\left(\mathrm{H}_{2} \mathrm{O}_{2}\right)$, which are regarded as being the result of disrupted equilibrium between their formation and clearance (5). ROS may attack intracellular biological macromolecules, including nuclear acids, proteins and lipids, induce dysfunction of mitochondria, and activate signaling pathways leading to apoptosis (6). Among the various ROS, $\mathrm{H}_{2} \mathrm{O}_{2}$ easily diffuses in and out of cells and tissues (6), and is readily converted into highly reactive hydroxyl radicals by the Fenton reaction (7). Thus, $\mathrm{H}_{2} \mathrm{O}_{2}$ has been considered to be an appropriate molecule to induce oxidative stress and is extensively used to investigate the protective effect of certain agents on cellular injury (8).

Lycopene, a lipid-soluble carotenoid compound, is often present in tomatoes and red fruits, including watermelon, pink grapefruit and guava (9). Although it has multiple biological functions, such as inhibition of inflammation, and suppression of cellular carcinogenesis and tumor growth $(10,11)$, accumulating evidence has indicated that lycopene exerts a strong protective effect against brain damage. A population-based follow-up study demonstrated that males in the highest quartile of serum lycopene concentrations exhibited 59 and 55\% lower risks of ischemic stroke when compared with males in the lowest quartile (12). Furthermore, animal experiments using rat models demonstrated that lycopene prevents brain injury caused by focal or global ischemia and reperfusion $(13,14)$, and alleviates cognition dysfunction induced by colchicine and rotenone $(15,16)$. In vitro research indicated that lycopene protects against neuronal apoptosis induced by different neurotoxic compounds, including 1-methyl-4-phenylpyridinium (MPP+), methylmercury, amyloid $\beta$, trimethyltin and 6-hydroxydopamine (17-21). Despite previous data, which revealed that lycopene possesses a potent antioxidant capacity (22) and inhibition of oxidative stress is the common mechanism responsible for its neuroprotection, the effect of lycopene on activation of neuronal apoptosis pathways remains unclear. 
SH-SY5Y cells are human neuroblastoma cells, which are comparable to neurons with regards to their morphological, neurochemical and electrophysiological properties and have been extensively applied to evaluate neuronal injury or death in neurodegenerative disease, cerebral ischemia/reperfusion and epilepsy (23-25). Therefore, the present study used $\mathrm{H}_{2} \mathrm{O}_{2}$-induced apoptosis in SH-SY5Y cells as a model to investigate the effect of lycopene on the activation of apoptotic pathways induced by oxidative stress.

\section{Materials and methods}

Drugs and chemicals. Lycopene was purchased from Sigma-Aldrich (St. Louis, MO, USA) and was dissolved in tetrahydrofuran (Sigma-Aldrich) prior to each experiment. $\mathrm{H}_{2} \mathrm{O}_{2}$ was purchased from Wuhan Boster Biological Technology, Ltd. (Wuhan, China). Superoxide Dismutase (SOD) activity and Catalase assay kits were obtained from BioVision Inc. (Milpitas, CA, USA). A lactate dehydrogenase (LDH) assay was purchased from Beyotime Institute of Biotechnology (Haimen, China). Rabbit anti-caspase-3 polyclonal antibody (ab44976), rabbit anti-apoptosis inducing factor (AIF) polyclonal antibody ab1998) and mouse anti- $\beta$-actin monoclonal antibody (ab8226) were purchased from Abcam (Cambridge, MA, USA). Rabbit anti-Bcl-2-like protein 4 (Bax) polyclonal antibody (cat. no. 2774) and rabbit anti-B-cell lymphoma 2 (Bcl-2; cat. no. 4223), rabbit anti-lamin B1 (cat. no. 13435), rabbit anti-cytochrome $c$ (Cyt $c$; cat. no. 4280) and mouse anti-cytochrome $c$ oxidase IV (COX IV; cat. no. 11967) monoclonal antibodies were from Cell Signaling Technology, Inc. (Danvers, MA, USA). Horseradish peroxidase (HRP)-conjugated goat anti-rabbit immunoglobulin (Ig) $\mathrm{G}$ and horse anti-mouse $\mathrm{IgG}$ were from Cell Signaling Technology, Inc. (cat. nos. 7074 and 7076, respectively). Enhanced chemiluminescence (ECL) western blotting detection reagents were purchased from GE Healthcare Life Sciences, and polyvinylidene difluoride (PVDF) membranes were from EMD Millipore (Billerica, MA, USA).

Cell culture and groups. Human SH-SY5Y neuroblastoma cells were obtained from Shanghai Institutes for Biological Sciences, Chinese Academy of Sciences (Shanghai, China). The cells were cultured in Dulbecco's modified Eagle's medium (DMEM; Thermo Fisher Scientific, Inc., Waltham, MA, USA) supplemented with $10 \%$ fetal bovine serum, $2 \mathrm{mmol} / \mathrm{l}$ glutamine (Sigma-Aldrich), $100 \mathrm{U} / \mathrm{ml}$ penicillin and $100 \mu \mathrm{g} / \mathrm{ml}$ streptomycin (Sigma-Aldrich), and maintained in a humid environment at $37^{\circ} \mathrm{C}$ and $5 \% \mathrm{CO}_{2}$ atmosphere. The medium was replaced twice per week.

The cells were randomized to the following groups: Control (normal SH-SYSY cells), lycopene (the cells were treated only with lycopene at the indicated concentrations), $\mathrm{H}_{2} \mathrm{O}_{2}$ (the cells were treated alone with $\mathrm{H}_{2} \mathrm{O}_{2}$ at indicated concentration), and $\mathrm{H}_{2} \mathrm{O}_{2}+$ lycopene (the cells were treated for $2 \mathrm{~h}$ with lycopene followed by a 24-h incubation with $\mathrm{H}_{2} \mathrm{O}_{2}$ ).

Cellular viability assay. A 3-(4,5-dimethylthiazol-2-yl)-2,5-diphenyltetrazolium bromide (MTT) colorimetric assay (Sigma-Aldrich) was performed to determine cell viability. SH-SY5Y cells were seeded at a density of $4 \times 10^{4}$ cells per well on collagen-coated 96-well plates for $24 \mathrm{~h}$. After being treated as described in each experimental group, the absorbance value at $570 \mathrm{~nm}$ was read using an automatic multi-well spectrophotometer (xMark ${ }^{\mathrm{TM}}$; Bio-Rad Laboratories, Inc., Richmond, CA, USA). The results are expressed as the percentage of MTT reduction relative to the absorbance of control cells.

LDH release assay. SH-SY5Y cells were seeded into 96-well culture plates at a density of $4 \times 10^{4}$ cells/well. The cells, with or without lycopene pretreatment, were incubated with $400 \mu \mathrm{mol} / 1 \mathrm{H}_{2} \mathrm{O}_{2}$ for $24 \mathrm{~h}$. According to the manufacturer's instructions, the supernatant from each sample was used in the LDH assay. The LDH activity was measured by monitoring the reduction of pyruvic acid. The absorbance of each sample was determined at $490 \mathrm{~nm}$ with a microplate reader $\left(\mathrm{xMark}^{\mathrm{TM}}\right)$. LDH release was expressed as the percentage (\%) of the total LDH activity (LDH in the medium + LDH in the cell), according to the following equation: $\% \mathrm{LDH}$ release $=(\mathrm{LDH}$ activity in the medium / total LDH activity) x100.

Detection of apoptosis by flow cytometry. Apoptosis was examined by analysis of DNA fragmentation using flow cytometry. After a 24-h incubation with $400 \mu \mathrm{mol} / 1 \mathrm{H}_{2} \mathrm{O}_{2}$ following a 2-h treatment with or without lycopene, SH-SY5Y cells were collected by $0.25 \%$ trypsin (Sigma-Aldrich) and washed once with phosphate-buffered saline (PBS). The cells were then fixed in $70 \%$ ethanol at $4^{\circ} \mathrm{C}$ overnight, treated with $100 \mathrm{mg} / \mathrm{l} \mathrm{RNase}$ (Sigma-Aldrich) at $37^{\circ} \mathrm{C}$ for $30 \mathrm{~min}$ and stained with $50 \mathrm{mg} / \mathrm{l}$ propidium iodide (Sigma-Aldrich) for $30 \mathrm{~min}$. Finally, the cells were analyzed using flow cytometry (FACScan; BD Biosciences, San Jose, CA, USA). The rate of apoptosis was analyzed using CellQuest software, version 5.1 (BD Biosciences). Data acquisition was conducted by collecting 20,000 cells per tube, and the numbers of viable and apoptotic cells were determined for each experimental condition.

Transmission electron microscopy. SH-SY5Y cells from the control group and $400 \mu \mathrm{mol} / 1 \mathrm{H}_{2} \mathrm{O}_{2}$ group were harvested using $0.25 \%$ trypsin, washed with PBS, collected by centrifugation for $10 \mathrm{~min}$ at $1,500 \mathrm{x} \mathrm{g}$ and treated as previously described by Watkins and Cullen (26). Briefly, the cells were fixed in ice-cold 2.5\% glutaraldehyde (Sigma-Aldrich) in PBS (pH 7.3), rinsed with PBS, post-fixed in $1 \%$ osmium tetroxide (Sigma-Aldrich) with $0.1 \%$ potassium ferricyanide (Sigma-Aldrich), dehydrated through a graded series of ethanol (30-90\%) and embedded in Epon (Energy Beam Sciences, Agawam, MA, USA). Semi-thin (300 nm) sections were sliced using a Reichart Ultracut E Ultra-Microtome (Leica Microsystems, Inc., Buffalo Grove, IL, USA), stained with 0.5\% Toluidine Blue (Sigma-Aldrich) and examined under a light microscope (Olympus IX71; Olympus Corporation, Tokyo, Japan). Ultra-thin sections $(65 \mathrm{~nm})$ were stained with $1 \%$ uranyl acetate and $0.1 \%$ lead citrate (both Sigma-Aldrich), and examined on a JEM-2000EX transmission electron microscope (JEOL USA, Inc., Pleasanton, CA, USA).

Hoechst 33342 staining. SH-SY5Y cells were seeded into 6 -well plates at a density of $2 \times 10^{5}$ cells/well. After pretreatment with or without lycopene, the cells were exposed to $400 \mu \mathrm{mol} / 1 \mathrm{H}_{2} \mathrm{O}_{2}$ for $24 \mathrm{~h}$, washed with PBS solution and 
loaded with $10 \mu \mathrm{g} / \mathrm{ml}$ Hoechst 33342 dye (Sigma-Aldrich) for $15 \mathrm{~min}$. The cells were subsequently visualized under a fluorescence microscope (Olympus IX71). Individual nuclei were visualized at a magnification of $x 400$ to distinguish the normal uniform nuclear pattern from the characteristic, condensed coalesced chromatin pattern of apoptotic cells. To quantify apoptosis, 400 nuclei from six random microscopic fields were analyzed by an observer blinded to the treatment groups. The total number of apoptotic cells in each section was summed and expressed as the percentage of the total cell number. A minimum of 10 individual sections were evaluated per slide.

Measurement of intracellular ROS levels. The average density of intracellular ROS was evaluated in cells loaded with the redox-sensitive dye, dichloro-dihydro-fluorescein diacetate (Molecular Probes DCFH-DA; Thermo Fisher Scientific, Inc.). SH-SY5Y cells, with or without lycopene pretreatment, were seeded into 96-well culture plates at a density of $4 \times 10^{4}$ cells/well, exposed for $24 \mathrm{~h}$ to $400 \mu \mathrm{mol} / 1 \mathrm{H}_{2} \mathrm{O}_{2}$, washed twice with PBS, stained with $20 \mu \mathrm{mol} / 1$ DCFH-DA in the dark for $30 \mathrm{~min}$ and harvested. The cells were then dissolved with 1\% Triton X-100 (Sigma-Aldrich). Fluorescence was observed under a fluorescent light microscope, and measured at excitation and emission wavelengths of 485 and $530 \mathrm{~nm}$, respectively using a fluorescence spectrometer (HTS 7000; PerkinElmer, Inc., Waltham, MA, USA). The ROS levels were expressed as arbitrary unit/mg protein and as a percentage of the control.

Measurement of mitochondrial membrane potential. Mitochondrial membrane potential was determined by the retention of the dye, rhodamine 123 (Sigma-Aldrich). SH-SY5Y cells, with or without lycopene pretreatment, were exposed for $24 \mathrm{~h}$ to $400 \mu \mathrm{mol} / 1 \mathrm{H}_{2} \mathrm{O}_{2}$. The cells were collected using $0.25 \%$ trypsin and washed twice with PBS, followed by incubation with $10 \mu \mathrm{g} / \mathrm{ml}$ rhodamine 123 at $37^{\circ} \mathrm{C}$ for $30 \mathrm{~min}$. The cells were washed again with PBS, and fluorescence intensities of rhodamine 123 in cells were analyzed by flow cytometry (FACScan).

Determination of mitochondrial permeability transition pore (MPTP) opening. The opening of MPTP was determined using a calcein-cobalt assay kit (Genmed Scientifics, Inc., Wilmington, DE, USA) as described previously (20). Briefly, SH-SY5Y cells were seeded into 24-well plates at a density of $5 \times 10^{4}$ cells/well. After pretreatment with or without lycopene, the cells were exposed to $400 \mu \mathrm{mol} / \mathrm{l}_{2} \mathrm{O}_{2}$ for $24 \mathrm{~h}$, washed twice with $1 \mathrm{ml}$ Reagent $\mathrm{A}$, incubated for $20 \mathrm{~min}$ at $37^{\circ} \mathrm{C}$ with $250 \mu \mathrm{l}$ each of Reagents B (calcein AM) and C (cobalt dichloride; 1:50; $500 \mu 1$ per well). The cells were subsequently washed twice with pre-warmed Reagent A. The fluorescence intensity was measured on a microplate reader with excitation and emission wavelengths of 488 and $505 \mathrm{~nm}$, respectively. After the fluorescence intensity was determined, the protein concentration for each well was measured using a Bradford protein assay kit (Bio-Rad Laboratories, Inc.). The fluorescent signals were normalized to total protein content in the corresponding cell extract and data were presented as normalized relative fluorescence units.

Measurement of cellular anti-oxidative enzymes. The activity of antioxidant enzymes, SOD and catalase were measured according to the manufacturer's instructions. After incubation for $24 \mathrm{~h}$ with $400 \mu \mathrm{mol} / 1 \mathrm{H}_{2} \mathrm{O}_{2}$ following pretreatment with or without lycopene, $\mathrm{SH}-\mathrm{SY} 5 \mathrm{Y}$ cells were collected from the culture dishes using a scraper, centrifuged at $1,000 \mathrm{x} g$ for $10 \mathrm{~min}$ at $4^{\circ} \mathrm{C}$, and the cell pellets were washed with PBS. For the SOD activity assay, the cells were suspended in ice-cold lysis buffer [0.1 M Tris/HCl (pH 7.4), $0.25 \mathrm{~mol} / 1$ sucrose, $5 \mathrm{mmol} / \mathrm{l} \beta$-mercaptoethanol and $0.1 \mathrm{mg} / \mathrm{ml}$ phenylmethylsulfonyl fluoride (PMSF); Sigma-Aldrich], homogenized with a glass Pyrex microhomogenizer (20 strokes; Beyotime Institute of Biotechnology), and centrifuged at 1,500 $\mathrm{x} g$ for 5 min at $4^{\circ} \mathrm{C}$. The supernatant was then collected for assaying. For the catalase activity assay, the cells were suspended in ice-cold assay buffer (Sigma-Aldrich), homogenized with a glass Pyrex microhomogenizer (20 strokes), centrifuged at $10,000 \mathrm{x}$ g for $15 \mathrm{~min}$ at $4^{\circ} \mathrm{C}$. The supernatant was then collected for assaying. The catalase was spectrophotometrically determined by measuring decreased absorbance at $570 \mathrm{~nm}$, using the catalase assay kit, and SOD was measured spectrophotometrically by monitoring the absorbance at $450 \mathrm{~nm}$ using the SOD assay kit. Catalase and SOD activities were expressed as $\mathrm{U} / \mathrm{mg}$ protein.

Immunocytochemistry. The collected SH-SY5Y cells were washed with PBS and fixed in $4.0 \%$ paraformaldehyde (Sigma-Aldrich) for $30 \mathrm{~min}$ at $4^{\circ} \mathrm{C}$. After being washed with PBS three times for $5 \mathrm{~min}$ each time, cells were incubated with $1 \%$ Triton X-100 for $10 \mathrm{~min}$, and blocked at nonspecific antibody binding sites by incubating with $5 \%$ bovine serum albumin (BSA; Sigma-Aldrich) in PBS containing 0.3\% Triton X-100 for $1 \mathrm{~h}$ at room temperature. The cells were then incubated with a polyclonal antibody against AIF (1:100) at $4^{\circ} \mathrm{C}$ overnight followed by incubation in cy3-conjugated goat anti-rabbit $\operatorname{IgG}(1: 200)$ for $50 \mathrm{~min}$ at room temperature. After washing with PBS, cells were incubated with Hoechst 33342 for $30 \mathrm{~min}$. After three washes, the cells were mounted on slides and visualized under a fluorescence microscope.

Differential centrifugation and cellular fraction. The collected cells were washed with PBS, and centrifuged for $10 \mathrm{~min}$ at $1,000 \mathrm{x} \mathrm{g}$, after which the cell pellets were suspended in ice-cold lysis buffer containing $15 \mathrm{mmol} / 1$ Tris, $\mathrm{pH} 7.6$, $250 \mathrm{mmol} / 1$ sucrose, $1 \mathrm{mmol} / 1 \mathrm{MgCl}_{2}, 2.5 \mathrm{mmol} / 1$ EDTA, $1 \mathrm{mmol} / \mathrm{l}$ ethylene glycol-bis ( $\beta$-aminoethyl ether) tetraacetic acid, $1 \mathrm{mmol} / 1$ dithiothreitol, $1.25 \mathrm{mg} / \mathrm{ml}$ pepstatin A, $10 \mathrm{mg} / \mathrm{ml}$ leupeptin, $2.5 \mathrm{mg} / \mathrm{ml}$ aprotinin, $1.0 \mathrm{mmol} / 1 \mathrm{PMSF}$, $0.1 \mathrm{mmol} / 1 \mathrm{Na}_{3} \mathrm{VO}_{4}, 50 \mathrm{mmol} / \mathrm{l} \mathrm{NaF}$, and $2 \mathrm{mmol} / 1 \mathrm{Na}_{4} \mathrm{P}_{2} \mathrm{O}_{7}$ (Sigma-Aldrich) and homogenized with a glass Pyrex microhomogenizer (20 strokes). The homogenates were centrifuged at $800 \mathrm{x} \mathrm{g}$ at $4^{\circ} \mathrm{C}$ for $10 \mathrm{~min}$ to obtain the pellet containing the nuclear fraction. The supernatants were then centrifuged at $15,000 \mathrm{x}$ g at $4^{\circ} \mathrm{C}$ for $10 \mathrm{~min}$ to obtain the pellet containing the mitochondria and the supernatant containing the cytosolic fraction. All the pellets were resuspended in lysis buffer. The protein content of each cellular fraction was determined using the Bradford protein assay kit.

Gel electrophoresis and western blotting. Equal protein quantities were electrophoresed on $10 \%$ sodium dodecyl sulfate-polyacrylamide gels and then transferred to PVDF 
membranes. The membranes were blocked with $3 \%$ BSA in Tris-buffered saline for $30 \mathrm{~min}$ and then incubated overnight at $4^{\circ} \mathrm{C}$ with primary antibodies against AIF $(1: 1,000)$, Bax (1:1,000), Bcl-2 (1:1,000), caspase-3 (1:1,000), Cyt $c(1: 1,000)$, COX IV $(1: 1,000), \beta$-actin $(1: 3,000)$ and lamin B1 $(1: 1,000)$. After being incubated with HRP-conjugated goat anti-rabbit $\operatorname{IgG}(1: 2,000)$ or horse anti-mouse $\operatorname{IgG}(1: 2,000)$, blots were washed and immunoreactive proteins were visualized on a Kodak X-omat LS film (Eastman Kodak Co., New Haven, CT, USA) with ECL. Densitometry was performed using Kodak ID Image Analysis Software, version 3.4.5 (Eastman Kodak Co.).

Statistical analysis. All data represent at least four independent experiments and are expressed as means \pm standard deviation. Statistical comparisons were conducted using one-way analysis of variance and $\mathrm{P}<0.05$ was considered to indicate a statistically significant difference.

\section{Results}

Lycopene inhibited $\mathrm{H}_{2} \mathrm{O}_{2}$-induced cell death in $\mathrm{SH}$-SY5Y cells. $\mathrm{H}_{2} \mathrm{O}_{2}$-induced changes in the viability of SH-SY5Y cells were firstly examined by MTT assay. When compared with the control group, the viability of the cells exposed for $24 \mathrm{~h}$ to $\mathrm{H}_{2} \mathrm{O}_{2}$ at the indicated concentrations decreased significantly (Fig. 1A; $\mathrm{P}<0.01$ ). Furthermore, the $\mathrm{H}_{2} \mathrm{O}_{2}$-induced reduction in cellular viability was concentration-dependent. Given that the viability of the cells treated with $400 \mu \mathrm{mol} / 1 \mathrm{H}_{2} \mathrm{O}_{2}$ reduced to $52.1 \pm 2.3 \%$ in comparison with that in the control group, the $400-\mu \mathrm{mol} / 1$ concentration was used in subsequent experiments to examine the effect of lycopene on $\mathrm{H}_{2} \mathrm{O}_{2}$-induced changes in SH-SY5Y cells.

As shown in Fig. 1B, no obvious differences were identified in the cellular viability between the cells in the control group and the cells treated lycopene alone at the indicated concentrations. By contrast, decreased cellular viability caused by 400 umol/1 $\mathrm{H}_{2} \mathrm{O}_{2}$ was improved significantly by pretreatment with lycopene at the concentration of 2.0,4.0 and $8.0 \mu \mathrm{mol} / 1$ lycopene $(\mathrm{P}<0.01)$, despite no significant difference being observed in the protective effect of lycopene between the 4.0 and $8.0 \mu \mathrm{mol} / 1$ groups.

Additionally, the effect of lycopene on $\mathrm{H}_{2} \mathrm{O}_{2}$-induced toxicity was examined by measuring the quantity of $\mathrm{LDH}$ in the culture medium. As Fig. 1C shows, the leakage of LDH significantly increased to $1,250.6 \pm 85.8 \%$ in the group exposed to $400 \mu \mathrm{mol} / 1$ $\mathrm{H}_{2} \mathrm{O}_{2}$ when compared with that in the control group $(\mathrm{P}<0.01)$. However, the elevated LDH leakage caused by $\mathrm{H}_{2} \mathrm{O}_{2}$ was suppressed to $962.5 \pm 79.8$ and $378.9 \pm 36.7 \%$ by pretreatment with 2.0 and $4.0 \mu \mathrm{mol} / 1$ lycopene, respectively (Fig. 1C; $\mathrm{P}<0.01$ ). These results indicate that lycopene exerts a protective effect on cells exposed to a lethal concentration of $\mathrm{H}_{2} \mathrm{O}_{2}$.

Lycopene inhibited $\mathrm{H}_{2} \mathrm{O}_{2}$-induced apoptosis in $\mathrm{SH}-\mathrm{SY} 5 \mathrm{Y}$ cells. Apoptosis is a form of programmed neuronal death caused by $\mathrm{H}_{2} \mathrm{O}_{2}$ (27); therefore, the present study examined the effect of lycopene on $\mathrm{H}_{2} \mathrm{O}_{2}$-induced apoptosis in $\mathrm{SH}-\mathrm{SY} 5 \mathrm{Y}$ cells. Fluorescence microscopy in combination with Hoechst 33342 staining showed that the nuclei in the $\mathrm{H}_{2} \mathrm{O}_{2}$ group were polygonal, condensed and bright blue in color
A

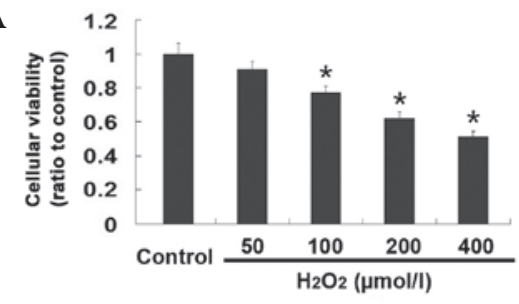

B
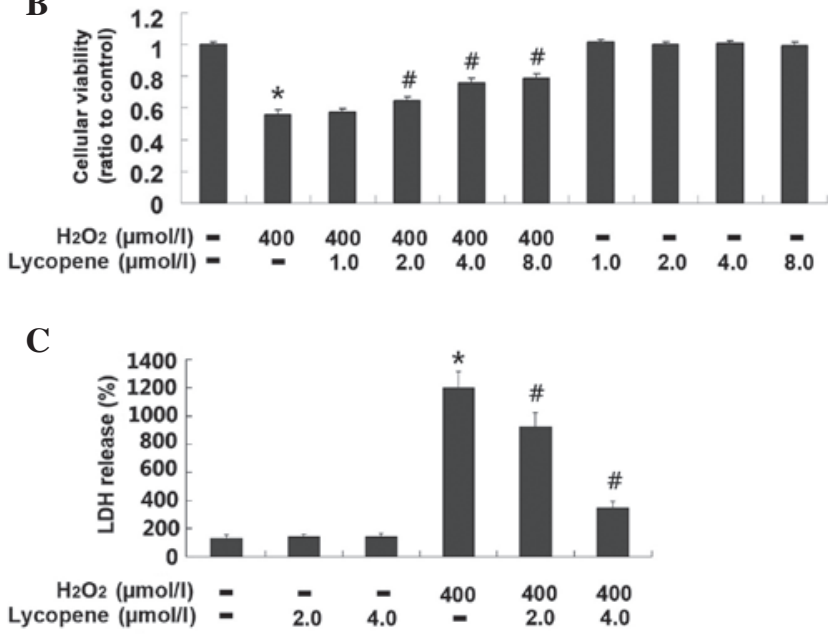

Figure 1. Lycopene inhibited $\mathrm{H}_{2} \mathrm{O}_{2}$-induced cell death in $\mathrm{SH}-\mathrm{SY} 5 \mathrm{Y}$ cells. (A) MTT assay of the viability of SH-SY5Y cells exposed to $\mathrm{H}_{2} \mathrm{O}_{2}$ for $24 \mathrm{~h}$ at the indicated concentrations. (B) MTT assay of the changes in the viability of SH-SY5Y cells exposed to $\mathrm{H}_{2} \mathrm{O}_{2}$ as a result of pretreatment with lycopene. (C) LDH release assay of $\mathrm{H}_{2} \mathrm{O}_{2}$-induced toxicity in $\mathrm{SH}-\mathrm{SY} 5 \mathrm{Y}$ cells pretreated with or without lycopene. ${ }^{*} \mathrm{P}<0.01$ vs. control group; ${ }^{\text {}} \mathrm{P}<0.01$ vs. $\mathrm{H}_{2} \mathrm{O}_{2}$ group. $\mathrm{H}_{2} \mathrm{O}_{2}$, hydrogen peroxide; LDH, lactate dehydrogenase; MTT, 3-(4,5-dimethylthiazol-2-yl)-2,5-diphenyltetrazolium bromide.

when compared with those in the control group (Fig. 2A). Cell counting under a florescence microscope demonstrated that the percentage of cells with apoptotic features was $32.6 \pm 4.8 \%$ in the $\mathrm{H}_{2} \mathrm{O}_{2}$ group, which was significantly higher than in the control group $(5.2 \pm 0.7 \% ; \mathrm{P}<0.01)$. However, this reduced to $25.1 \pm 1.9$ and $15.2 \pm 1.7 \%$ in the cells pretreated with 2.0 and $4.0 \mu \mathrm{mol} / 1$ lycopene, respectively (Fig. 2B). Fig. 2C demonstrates the transmission electronic microscopy images of the cells exposed to $\mathrm{H}_{2} \mathrm{O}_{2}$, demonstrating membrane blebbing, chromatin accumulation beneath the nucleus membrane and nucleus condensation, which are consistent with the morphological features of apoptotic cells (Fig. 2C). Furthermore, flow cytometry indicated that the apoptosis rate in the control and $\mathrm{H}_{2} \mathrm{O}_{2}$ groups was 3.21 and $42.04 \%$, respectively. By contrast, 2.0 and $4.0 \mu \mathrm{mol} / 1$ lycopene decreased the apoptosis rate to 26.55 and $17.87 \%$, respectively (Fig. 2D). These results indicate that lycopene protects $\mathrm{SH}-\mathrm{SY} 5 \mathrm{Y}$ cells against $\mathrm{H}_{2} \mathrm{O}_{2}$-induced death via inhibition of apoptosis.

Lycopene mitigated oxidative stress caused by $\mathrm{H}_{2} \mathrm{O}_{2}$. ROS is an important indicator of oxidative stress, which is also a trigger of apoptosis. Therefore, ROS production caused by $\mathrm{H}_{2} \mathrm{O}_{2}$ was examined in cells pretreated with or without lycopene. The green fluorescence in the group exposed to $400 \mu \mathrm{mol} / 1 \mathrm{H}_{2} \mathrm{O}_{2}$ was observed to be markedly stronger than that in the control group, however, was attenuated by pretreatment with either 2.0 or $4.0 \mu \mathrm{mol} / 1$ lycopene 
A

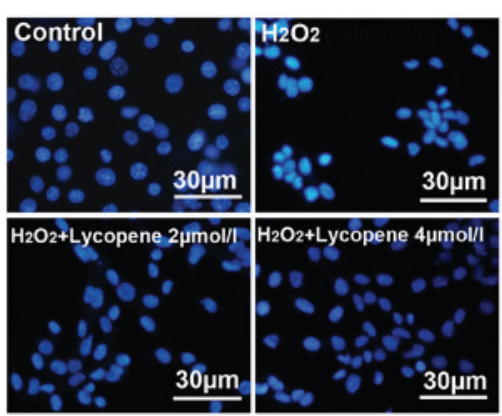

C

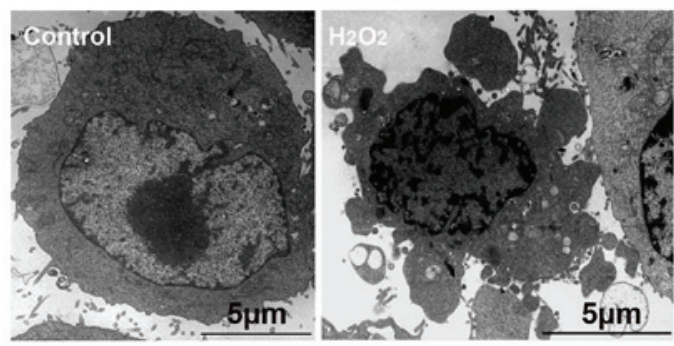

B

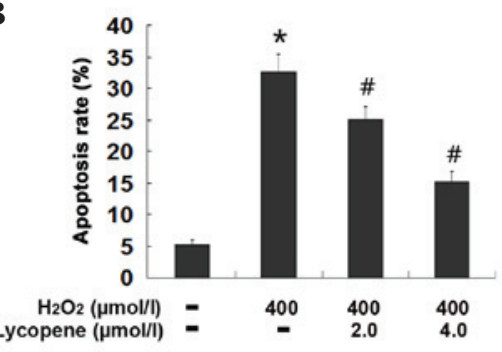

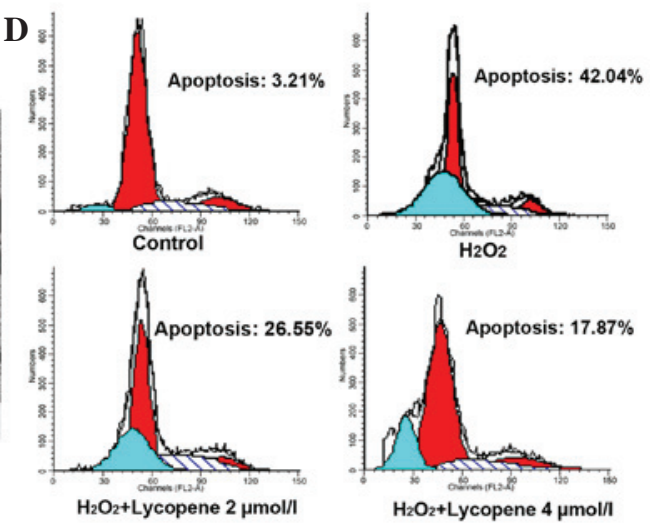

Figure 2. Lycopene inhibited $\mathrm{H}_{2} \mathrm{O}_{2}$-induced apoptosis in SH-SY5Y cells. (A) Representative images of nuclei stained with Hoechst 33342. (B) Quantification of the nuclei demonstrating apoptotic features observed under a fluorescence microscope. (C) Representative images of the control and apoptotic cells observed under a transmission electronic microscope. The cells treated with $\mathrm{H}_{2} \mathrm{O}_{2}$ had membrane blebbing, chromatin accumulation beneath the nuclear membrane and nuclear condensation. (D) Flow cytometric analysis of the effect of lycopene on $\mathrm{H}_{2} \mathrm{O}_{2}$-induced apoptosis in $\mathrm{SH}-\mathrm{SY} 5 \mathrm{Y}$ cells. ${ }^{*} \mathrm{P}<0.01$ vs. control group; ${ }^{\#} \mathrm{P}<0.01$ vs. $\mathrm{H}_{2} \mathrm{O}_{2}$ group. $\mathrm{H}_{2} \mathrm{O}_{2}$, hydrogen peroxide.

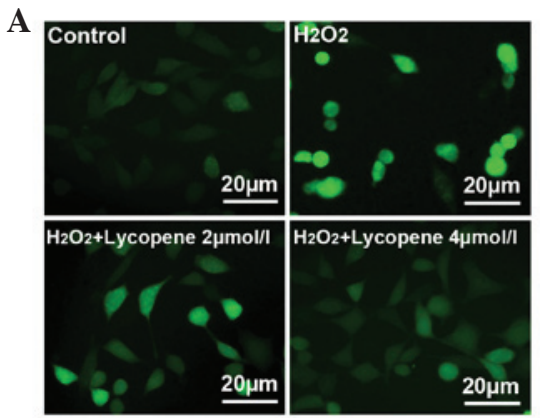

B

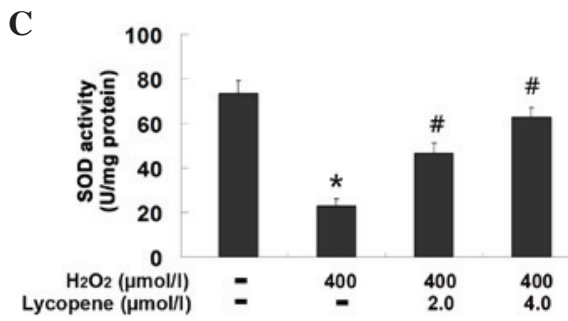

Figure 3. Lycopene mitigated $\mathrm{H}_{2} \mathrm{O}_{2}$-induced oxidative stress in SH-SY5Y cells. (A) Representative fluorescence microscopy images of the cells stained with DCFH-DA. (B) Quantification of fluorescence density of the cells stained with DCFH-DA. (C) Activity assay of SOD. (D) Activity assay of catalase. "P $<0.01$ vs. control group. ${ }^{*} \mathrm{P}<0.01$ vs. $\mathrm{H}_{2} \mathrm{O}_{2}$ group. DCFH-DA, dichloro-dihydro-fluorescein diacetate; DCF, 2', 7'-dichlorofluorescein; SOD, superoxide dismutase; $\mathrm{H}_{2} \mathrm{O}_{2}$, hydrogen peroxide.

(Fig. 3A). Additionally, the spectrometric assay showed that the fluorescence intensity in the $400 \mu \mathrm{mol} / 1 \mathrm{H}_{2} \mathrm{O}_{2}$ group was $2.83 \pm 0.21$ times higher than that in the control group $(\mathrm{P}<0.01)$, but reduced to $2.34 \pm 0.19$ times and $1.67 \pm 0.15$ times in the cells pretreated with 2.0 and $4.0 \mu \mathrm{mol} / \mathrm{l}$ lycopene,
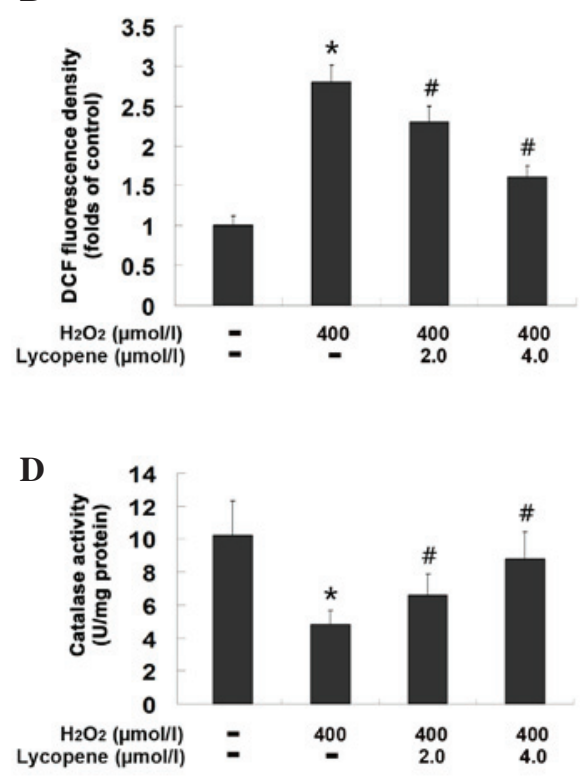
A
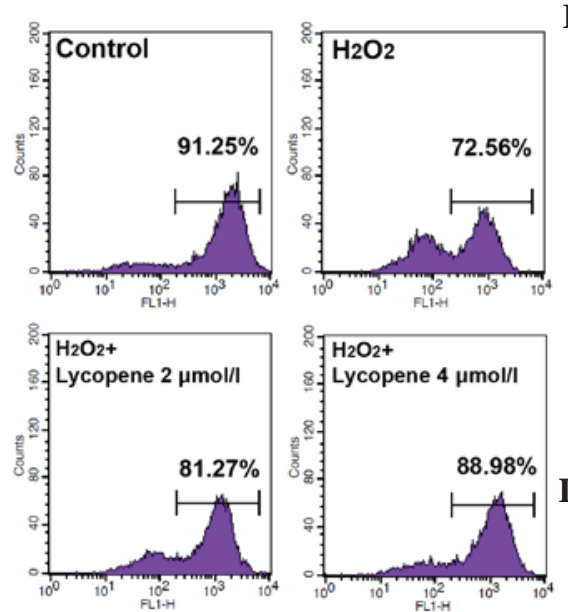

C

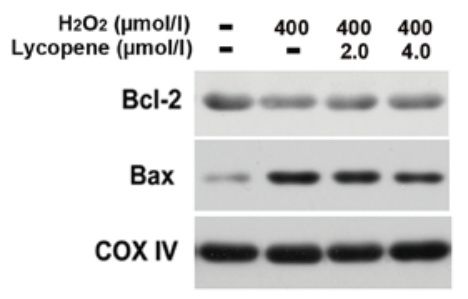

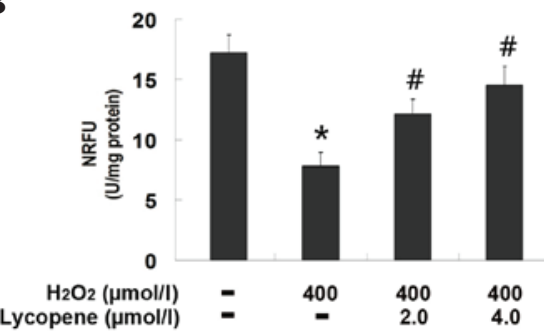
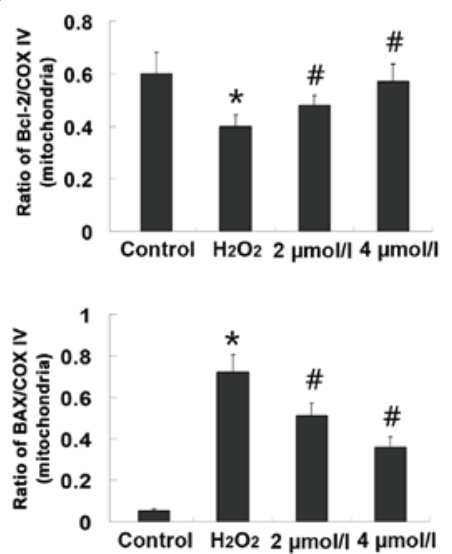

Figure 4. Lycopene counteracted mitochondrial dysfunction caused by $\mathrm{H}_{2} \mathrm{O}_{2}$. (A) Measurement of mitochondrial permeability transition pore opening. (B) Analysis of mitochondrial membrane potentials by flow cytometry. (C) Western blot analysis of Bax and Bcl-2 protein levels within mitochondria. (D) Quantification of Bax and Bcl-2 protein levels. ${ }^{*} \mathrm{P}<0.01$ vs. control group. ${ }^{\#} \mathrm{P}<0.01$ vs. $\mathrm{H}_{2} \mathrm{O}_{2}$ group. NRFU, normalized relative fluorescence units; Bcl-2, B-cell lymphoma 2; Bax, Bcl-2-like protein 4; COX IV, cytochrome $c$ oxidase subunit IV; $\mathrm{H}_{2} \mathrm{O}_{2}$, hydrogen peroxide.

matic activities of SOD and catalase were examined in the present study. As shown in Fig. 3C and D, the activity of SOD in the cells exposed to $400 \mu \mathrm{mol} / 1 \mathrm{H}_{2} \mathrm{O}_{2}$ was $22.8 \pm 3.23 \mathrm{U} / \mathrm{mg}$ protein, significantly lower than $73.66 \pm 5.39 \mathrm{U} / \mathrm{mg}$ protein in the control group $(\mathrm{P}<0.01)$. By contrast, it was improved to $46.72 \pm 4.53$ and $62.77 \pm 5.36 \mathrm{U} / \mathrm{mg}$ protein in the cells pretreated with 2.0 and $4.0 \mu \mathrm{mol} / 1$ lycopene, respectively ( $\mathrm{P}<0.01$ vs. the $\mathrm{H}_{2} \mathrm{O}_{2}$ group). Similarly, the catalase activity reduced from $10.22 \pm 2.11$ to $4.81 \pm 0.88 \mathrm{U} / \mathrm{mg}$ protein when $\mathrm{SH}-\mathrm{SY} 5 \mathrm{Y}$ cells were exposed to $400 \mu \mathrm{mol} / 1 \mathrm{H}_{2} \mathrm{O}_{2}(\mathrm{P}<0.01)$, whereas pretreatment with 2.0 and $4.0 \mu \mathrm{mol} / 1$ lycopene restored its activity to $6.58 \pm 1.28$ and $8.76 \pm 1.69 \mathrm{U} / \mathrm{mg}$ protein, respectively $\left(\mathrm{P}<0.01 \mathrm{vs}\right.$. the $\mathrm{H}_{2} \mathrm{O}_{2}$ group). These results indicate that lycopene facilitates the maintenance of SOD and catalase activities in the cells exposed to $\mathrm{H}_{2} \mathrm{O}_{2}$.

Lycopene protected against $\mathrm{H}_{2} \mathrm{O}_{2}$-induced mitochondrial dysfunction. Mitochondrial dysfunction due to ROS attack is proposed to participate in cellular apoptosis. Therefore, depolarization of the mitochondrial membrane and opening of the MPTP, which are sensitive indicators of mitochondrial function, were assayed in the present study. As shown in Fig. 4A, the mitochondrial membrane potentials reduced from 91.25 to $72.56 \%$ after the SH-SY5Y cells were exposed to $\mathrm{H}_{2} \mathrm{O}_{2}$. However, the mitochondrial membrane potentials were restored to 81.27 and $88.98 \%$ in the groups pretreated with 2.0 and $4.0 \mu \mathrm{mol} / 1$ lycopene, respectively. This indicates that pretreatment with lycopene inhibits $\mathrm{H}_{2} \mathrm{O}_{2}$-induced depolarization of the mitochondrial membrane in SH-SY5Y cells.
Similar changes were observed in the MPTP opening (Fig. 4B). Compared with the control group, the fluorescence intensity of cells in the $\mathrm{H}_{2} \mathrm{O}_{2}$ group was significantly weakened (from $17.22 \pm 1.51$ to $7.83 \pm 1.12$; $\mathrm{P}<0.01$ ), which was indicative of the opening of the MPTP. When the cells were pretreated with lycopene at concentrations of 2.0 or $4.0 \mu \mathrm{mol} / 1$, the fluorescence intensity was significantly strengthened to 12.18 $\pm 1.33(\mathrm{P}<0.01)$ and $14.49 \pm 1.47(\mathrm{P}<0.01)$, respectively, indicating closure of the MPTP.

Since it has been reported that $\mathrm{Bax}$ and $\mathrm{Bcl}-2$ regulate the opening of MPTP (28), the mitochondrial fraction was isolated via differential centrifugation, and the levels of Bax and Bcl-2 were examined by western blotting (Fig. 4C). The protein expression level of Bax was significantly increased from $0.05 \pm 0.01$ to $0.72 \pm 0.08(\mathrm{P}<0.01)$, and the expression level of Bcl-2 was significantly decreased from $0.61 \pm 0.07$ to $0.38 \pm 0.04(\mathrm{P}<0.01)$, in the mitochondria of the cells exposed to $\mathrm{H}_{2} \mathrm{O}_{2}$ when compared with those in the control group (Fig. 4D). By contrast, the changes in the expression levels of Bax and Bcl-2 within the mitochondria were reversed by pretreatment with 2.0 and $4.0 \mu \mathrm{mol} / 1$ lycopene. Following pretreatment with $2.0 \mu \mathrm{mol} / 1$ lycopene, the expression levels of Bax were decreased to $0.51 \pm 0.06$ and the expression levels of Bcl-2 were increased to $0.48 \pm 0.04$. Notably, $4.0 \mu \mathrm{mol} / 1 \mathrm{demon}-$ strated stronger effects compared with $2.0 \mu \mathrm{mol} / 1$ lycopene; the expression levels of Bax were decreased to $0.35 \pm 0.04$ and those of Bcl-2 were increased to $0.57 \pm 0.07$ following pretreatment with $4.0 \mu \mathrm{mol} / 1$ lycopene (Fig. 4D). These results indicate 
A

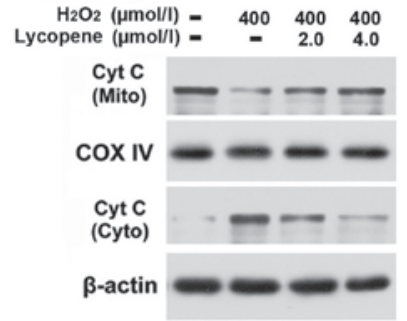

C

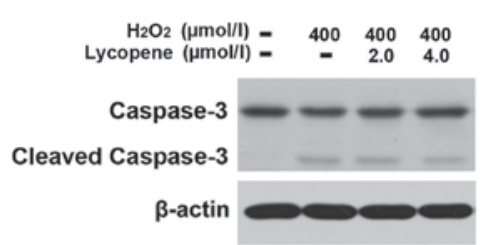

B
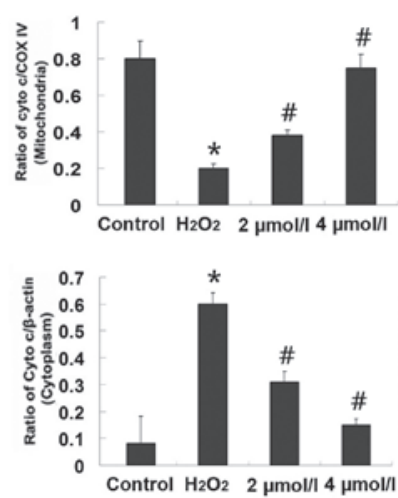

D

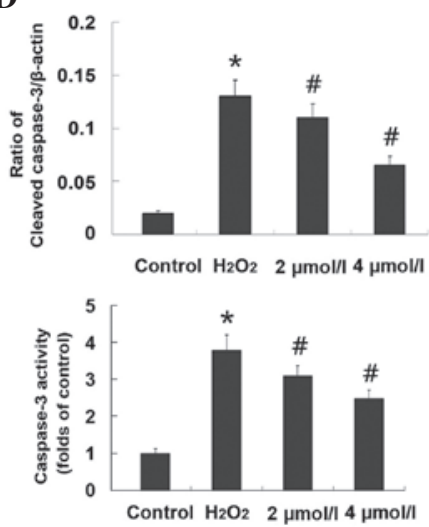

Figure 5. Lycopene attenuated the release of Cyt $c$ from the mitochondria to the cytoplasm and inhibited the activation of caspase-3. (A) Western blot analysis of translocation of Cyt $c$ from the mitochondria (Mito) to the cytoplasm (Cyto). (B) Quantification of the Cyt $c$ protein levels in the mitochondria and cytoplasm. (C) Western blot analysis of the expression level of cleaved caspase-3. (D) Quantification of the cleaved caspase-3 protein level. " $\mathrm{P}<0.01$ vs. control group. ${ }^{~} \mathrm{P}<0.01$ vs. $\mathrm{H}_{2} \mathrm{O}_{2}$ group. Cyt $c$, cytochrhome $c$; COX IV, cytochrome $c$ oxidase subunit IV; $\mathrm{H}_{2} \mathrm{O}_{2}$, hydrogen peroxide.

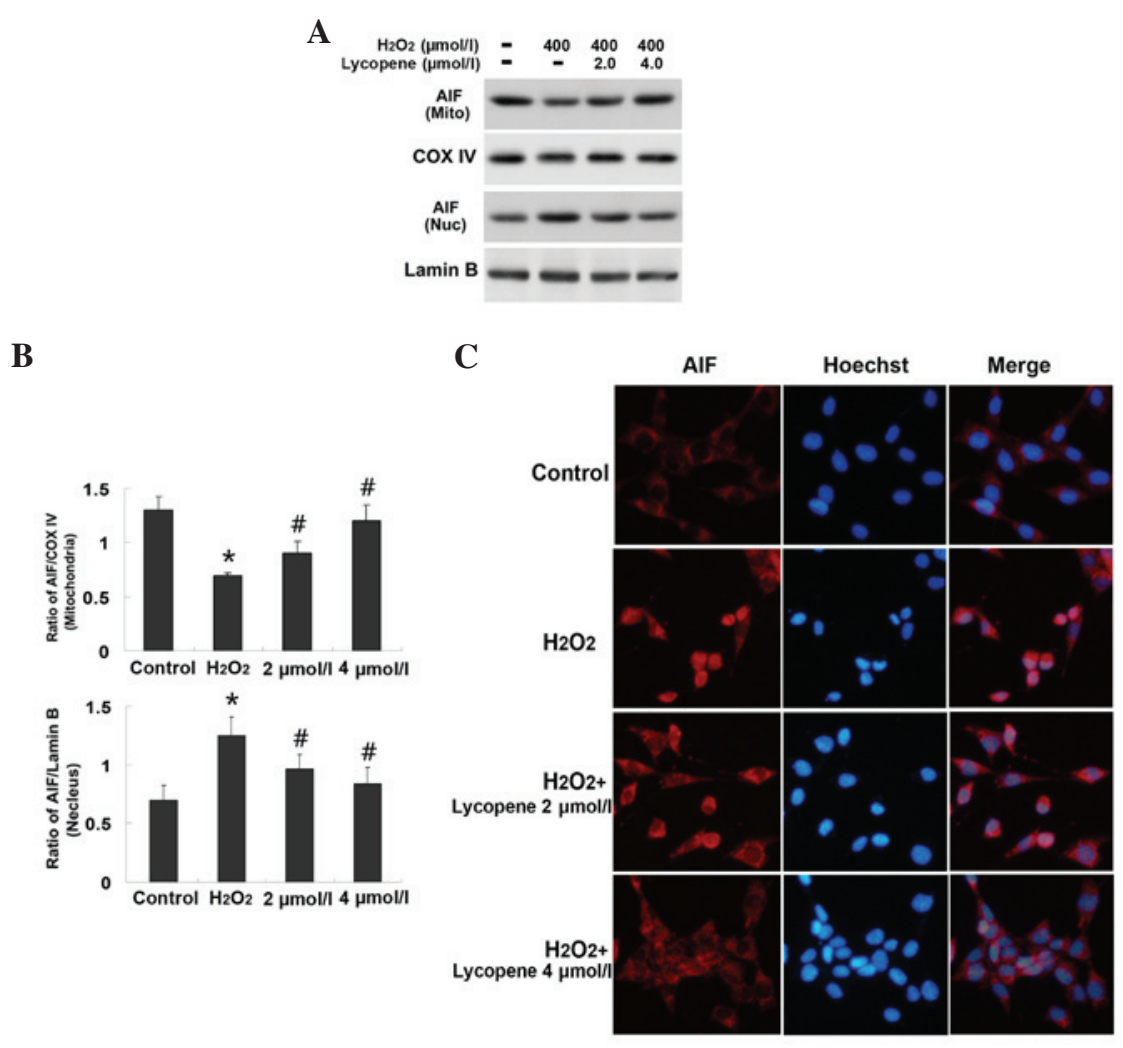

Figure 6. Lycopene suppressed the translocation of AIF from the mitochondria to the nuclei. (A) Western blot analysis of the AIF levels within the mitochondria (Mito) and nucleus (Nuc). (B) Quantification of the AIF levels. (C) Representative fluorescence microscopy images of the distribution of AIF. "P $<0.01$ vs. control group. ${ }^{\#} \mathrm{P}<0.01$ vs. $\mathrm{H}_{2} \mathrm{O}_{2}$ group. $\mathrm{H}_{2} \mathrm{O}_{2}$, hydrogen peroxide; AIF, apoptosis inducing factor; COX IV, cytochrome $c$ oxidase subunit IV. 
that lycopene is able to modulate the level of mitochondrial Bax and Bcl-2, which may clarify the molecular mechanism underlying the inhibitory effect of lycopene on $\mathrm{H}_{2} \mathrm{O}_{2}$-induced MPTP opening.

Lycopene inhibited the mitochondrial-associated apoptosis pathway. Mitochondrial proteins, including Cyt $c$ and AIF, are critical in the initiation of intrinsic apoptosis signaling pathways. Thus, the sub-cellular mitochondrial, nuclear and cytoplasm fractions were isolated, and the distribution of Cyt $c$ (Fig. 5) and AIF (Fig. 6) were examined by western blotting. The protein levels of Cyt $c$ and AIF within the mitochondria were significantly decreased from $0.82 \pm 0.13$ to $0.23 \pm 0.02$ $(\mathrm{P}<0.01)$ and $1.33 \pm 0.15$ to $0.73 \pm 0.03(\mathrm{P}<0.01)$, respectively, in the $\mathrm{H}_{2} \mathrm{O}_{2}$ group. Conversely, the level of Cyt $c$ was elevated from $0.08 \pm 0.07$ to $0.62 \pm 0.04(\mathrm{P}<0.01)$ in the cytoplasm, and the level of AIF was increased from $0.71 \pm 0.07$ to $1.25 \pm 0.16(\mathrm{P}<0.01)$ in the nucleus (Figs. 5 and 6). Cleaved caspase- 3 is a downstream apoptosis executor of the Cyt $c$ signaling pathway. Notably, the levels of cleaved caspase- 3 were increased from $0.02 \pm 0.0018$ to $0.13 \pm 0.015(\mathrm{P}<0.01)$, and the activity of caspase- 3 was elevated from $1.02 \pm 0.11$ to $3.83 \pm 0.42(\mathrm{P}<0.01)$, in the cells exposed to $\mathrm{H}_{2} \mathrm{O}_{2}$ (Fig. 5). In addition, immunocytochemistry demonstrated that a proportion of mitochondrial AIF translocated into the nuclei of the cells treated with $\mathrm{H}_{2} \mathrm{O}_{2}$ (Fig. 6). By contrast, pretreatment with lycopene at either 2.0 or $4.0 \mu \mathrm{mol} / 1$ suppressed these alterations in levels of Cyt $c$, cleaved caspase- 3 and AIF that were caused by $\mathrm{H}_{2} \mathrm{O}_{2}$ (Figs. 5 and 6). These results indicate that lycopene inhibits $\mathrm{H}_{2} \mathrm{O}_{2}$-induced apoptosis in SH-SY5Y cells via inhibition of caspase and AIF apoptotic pathways.

\section{Discussion}

The present study demonstrated that pretreatment with lycopene significantly inhibited $\mathrm{H}_{2} \mathrm{O}_{2}$-induced apoptosis in SH-SY5Y cells via attenuation of ROS production, protection against mitochondrial dysfunction and mitigation of the activation of mitochondria-associated apoptotic pathways. The underlying mechanisms of the inhibitory effects of lycopene on $\mathrm{H}_{2} \mathrm{O}_{2}$-induced apoptosis in SH-SY5Y cells are the inhibition of oxidative stress and suppression of mitochondria-associated apoptosis pathways.

Apoptosis is an important form of programmed neuronal death, which has been identified under various pathological conditions, such as cerebral ischemia, neurotrauma, and Parkinson's disease (29-31). $\mathrm{H}_{2} \mathrm{O}_{2}$-induced cell death in human $\mathrm{SH}-\mathrm{SY} 5 \mathrm{Y}$ cells is often used as an in vitro model to investigate neuronal apoptosis caused by oxidative stress $(27,32,33)$. In the current study, transmission electronic and fluorescence microscopy revealed that $\mathrm{SH}-\mathrm{SY} 5 \mathrm{Y}$ cells treated with $\mathrm{H}_{2} \mathrm{O}_{2}$ presented morphological features of apoptosis, including membrane blebbing, chromatin accumulation beneath the nucleus membrane and nucleus condensation. By contrast, pretreatment with lycopene significantly attenuated $\mathrm{H}_{2} \mathrm{O}_{2}$-induced apoptosis in SH-SY5Y cells, which was demonstrated by Hoechst 33342 staining and flow cytometric analysis. As previous reports demonstrated that lycopene prevented apoptosis (induced by cerebral ischemia and reperfusion) in gerbil hippocampal neurons and in cardiomyocytes (where apoptosis was induced in vitro by hypoxia and re-oxygenation) $(14,34)$, it was hypothesized that lycopene inhibits $\mathrm{H}_{2} \mathrm{O}_{2}$-induced death in SH-SY5Y cells via suppression of apoptosis.

Oxidative stress, characterized by accumulation of ROS, is proposed to be an initiator of neuronal apoptosis (35). The brain is an organ that is prone to producing reactive oxidative species (such as $\mathrm{O}_{2}^{-}, \mathrm{H}_{2} \mathrm{O}_{2}$ and hydroxyl radicals) as it requires a large quantity of oxygen to maintain its normal function, but is deficient in anti-oxidants (36). Furthermore, neuronal cells are more sensitive to oxidative stress than the cells in other types of tissue (37). Therefore, inhibition of oxidative stress is considered to be a strategy to prevent neuronal apoptosis. Previous studies have shown that lycopene is a potent agent that inhibits oxidative stress, which occurs within human cells. Tang et al (38) found that lycopene protected human endothelial cell against $\mathrm{H}_{2} \mathrm{O}_{2}$-induced oxidative injury. Palozza et al (39) reported that lycopene prevented 7-ketocholesterol-induced oxidative stress in human macrophages. Consistent with these previous findings, the present study found that lycopene significantly inhibited $\mathrm{H}_{2} \mathrm{O}_{2}$-induced accumulation of ROS in SH-SY5Y cells. Lycopene is a chemical found to inhibit oxidative stress by quenching singlet oxygen and trapping peroxyl radicals (10), which may elucidate why pretreatment with lycopene in the present study inhibited the ROS levels in the SH-SY5Y cells that were exposed to $\mathrm{H}_{2} \mathrm{O}_{2}$. Furthermore, it was demonstrated that lycopene mitigated the $\mathrm{H}_{2} \mathrm{O}_{2}$-induced reduction in SOD and catalase activities. Consistently, Srinivasan et al (40) reported that lycopene was able to recover the damaged activities of SOD and catalase in human lymphocytes caused by gamma-radiation. SOD and catalase are the predominant members of the intracellular enzymes that have the ability to clear ROS. SOD converts $\mathrm{O}_{2}{ }^{-}$into $\mathrm{H}_{2} \mathrm{O}_{2}$, which is subsequently transformed into water and oxygen via catalase. Therefore, maintaining the activities of the anti-oxidative enzymes, SOD and catalase is another method by which lycopene clears $\mathrm{H}_{2} \mathrm{O}_{2}$-indcued excessive ROS.

The mitochondrion is an organelle that may activate apoptosis when its function is damaged. ROS, which are produced during the process of oxidative stress, may target mitochondria, resulting in the opening of the MPTP and the decline in mitochondrial membrane potentials (41). Although it was observed that lycopene is an effective agent that could prevent mitochondrial dysfunction caused by $\mathrm{MPP}^{+}$ and hypoxia/reoxygenation $(17,34)$, its underlying molecular mechanism remains unclear. Previously, Sandhir et al (42) reported that lycopene maintained mitochondrial function by suppression of mitochondrial oxidative stress that was caused by 3 -nitropropionic acid in the rat brain. By contrast, the present study demonstrated that the inhibitory effect of lycopene on the $\mathrm{H}_{2} \mathrm{O}_{2}$-induced decline in mitochondrial membrane potentials and opening of MPTP in SH-SY5Y cells was associated with the fact that lycopene significantly counteracted the $\mathrm{H}_{2} \mathrm{O}_{2}$-induced increase in pro-apoptotic Bax level and reduction in anti-apoptotic Bcl-2 level within mitochondria. The Bax and Bcl-2 within mitochondria has been found to participate in the regulation of mitochondrial function, where Bax promotes and Bcl-2 blocks the formation and opening of MPTP (43). Furthermore, inhibition of MPTP opening has been identified as a promising therapeutic target for preventing cell damage (44). Therefore, the present study hypothesized 
that lycopene mitigated $\mathrm{H}_{2} \mathrm{O}_{2}$-induced mitochondrial dysfunction in SH-SY5Y cells by counteracting the $\mathrm{H}_{2} \mathrm{O}_{2}$-induced reduction in Bcl-2 and elevation in Bax expression levels.

It was reported previously that lycopene attenuated apoptosis via inhibition of the nuclear factor- $\kappa \mathrm{B}$ signaling pathway (45), alleviation of c-Jun N-terminal kinase activation (46), mitigation of endoplasmic reticulum stress (47) and induction of protective autophagy (48). In the present study, lycopene inhibited mitochondria-associated apoptotic pathways, which were activated in the SH-SY5Y cells that were exposed to $\mathrm{H}_{2} \mathrm{O}_{2}$. The opening of MPTP results in the release of pro-apoptotic proteins, Cyt $c$ and AIF, which are normally located in the space between the mitochondrial inner and outer membranes (45). After being released as a result of apoptotic stress, Cyt $c$ translocates into the cytoplasm to activate the caspase-dependent apoptotic pathway by cleaving caspase-3. Thus, cleaved caspase- 3 is often regarded as a marker representing the activation of caspase-3. In the current study, pretreatment with lycopene mitigated the release of Cyt $c$ from the mitochondria and suppressed the level of cleaved caspase-3 in SH-SY5Y cells that were exposed to $\mathrm{H}_{2} \mathrm{O}_{2}$. Results from previous studies indicate that inhibition of the activation of caspase- 3 is one factor that is responsible for the protection of lycopene against apoptosis in various types of cells $(19,38)$. $\mathrm{Qu}$ et al (19) reported that lycopene inhibited amyloid $\beta$-induced caspase- 3 activation in cultured rat cortical neurons and Tang et al (38) demonstrated that lycopene attenuated the level of activated caspase- 3 caused by $\mathrm{H}_{2} \mathrm{O}_{2}$ exposure in human endothelial cells. Thus, the inhibitory effect of lycopene on $\mathrm{H}_{2} \mathrm{O}_{2}$-induced apoptosis in SH-SY5Y cells is associated with its attenuation of caspase-3 apoptosis pathway activation.

AIF, as another protein that is released from the mitochondria of cells stressed by apoptotic stimuli, represents a caspase-independent apoptotic pathway. AIF translocates into the nucleus to initiate chromatin condensation and DNA fragmentation (49) and has been found to be involved in neuronal apoptosis caused by different neuropathological conditions. $\mathrm{Ba}$ et al (50) demonstrated that AIF nuclear translocation occurred following focal cerebral ischemia-reperfusion injury in rats. Yang et al (51) found that AIF translocation into nuclei contributed to epilepsy-induced apoptosis in hippocampal neurons in vitro. Thus, in vitro and in vivo studies have demonstrated that AIF is a crucial factor leading to neuronal injury or apoptosis. By contrast, in vitro and in vivo studies have demonstrated that inhibition of AIF translocation into nuclei is responsible for the protection of certain chemicals against neuronal apoptosis. Huang et al (52) reported that the protection of forsythiaside against $\mathrm{H}_{2} \mathrm{O}_{2}$-induced apoptosis in PC12 cells was associated with inhibiting the accumulation of AIF within the nuclei. Similarly, an in vivo study revealed that blocking the mitochondrio-nuclear translocation of AIF by ginsenoside Rd benefited neuronal survival following focal cerebral ischemia in rats (53). In the present study, the $\mathrm{H}_{2} \mathrm{O}_{2}$-induced elevation of AIF level within the nuclei of SH-SY5Y cells was observed to be suppressed when cells were pre-treated with lycopene. Although there was no report regarding the effect of lycopene on AIF translocation from the mitochondria into the nuclei, lycopene was demonstrated to inhibit $\mathrm{H}_{2} \mathrm{O}_{2}$-induced apoptosis in SH-SY5Y cells via mitigation of AIF nuclear translocation.
In conclusion, the present study demonstrated that lycopene inhibits $\mathrm{H}_{2} \mathrm{O}_{2}$-induced excessive production of ROS in SH-SY5Y cells by maintaining the activity of cellular anti-oxidative enzymes, SOD and catalase. Lycopene protects against mitochondrial dysfunction by counteracting $\mathrm{H}_{2} \mathrm{O}_{2}$-induced upregulation of Bax expression and downregulation of $\mathrm{Bcl}-2$ expression. Furthermore, lycopene suppressed $\mathrm{H}_{2} \mathrm{O}_{2}$-induced activation of caspase-3 and AIF apoptotic pathways in SH-SY5Y cells. Thus, lycopene is considered to be a potent agent that exerts a protective effect against oxidative stress, mitochondrial dysfunction and apoptosis, and may serve as a therapeutic strategy for preventing neuronal injury or death.

\section{Acknowledgements}

The present study was supported by the National Nature and Science Foundation of China (grant nos. 81171234 and $81271215)$, the Nature and Science Foundation of Jilin province (grant nos. 201115068 and 20121809) and the Bethune project of Jilin University (grant no. 2012203).

\section{References}

1. Chan PH: Reactive oxygen radicals in signaling and damage in the ischemic brain. J Cereb Blood Flow Metab 21: 2-14, 2001.

2. Yang T, Kong B, Gu JW, Kuang YQ, Cheng L, Yang WT, Xia X and Shu HF: Anti-apoptotic and anti-oxidative roles of quercetin after traumatic brain injury. Cell Mol Neurobiol 34: 797-804, 2014.

3. Aguiar CC, Almeida AB, Araújo PV, de Abreu RN, Chaves EM, do Vale OC, Macêdo DS, Woods DJ, Fonteles MM and Vasconcelos SM: Oxidative stress and epilepsy: Literature review. Oxid Med Cell Longev 2012: 795259, 2012.

4. Cahill-Smith S and Li JM: Oxidative stress, redox signalling and endothelial dysfunction in ageing-related neurodegenerative diseases: A role of NADPH oxidase 2. Br J Clin Pharmacol 78: 441-453, 2014.

5. Aliev G, Smith MA, Seyidov D, Neal ML, Lamb BT, Nunomura A, Gasimov EK, Vinters HV, Perry G, LaManna JC and Friedland RP: The role of oxidative stress in the pathophysiology of cerebrovascular lesions in Alzheimer's disease. Brain Pathol 12: 21-35, 2002.

6. Barbouti A, Doulias PT, Nousis L, Tenopoulou M and Galaris D: DNA damage and apoptosis in hydrogen peroxide-exposed Jurkat cells: Bolus addition versus continuous generation of $\mathrm{H}(2)$ O(2). Free Radic Biol Med 33: 691-702, 2002.

7. Tian X, Guo LP, Hu XL, Huang J, Fan YH, Ren TS and Zhao QC: Protective Effects of Arctium lappa L. roots against hydrogen peroxide-induced cell injury and potential mechanisms in SH-SY5Y cells. Cell Mol Neurobiol 35: 335-344, 2015.

8. Jiang J, Yu S, Jiang Z, Liang C, Yu W, Li J, Du X, Wang H, Gao X and Wang X: N-acetyl-serotonin protects HepG2 cells from oxidative stress injury induced by hydrogen peroxide. Oxid Med Cell Longev 2014: 310504, 2014.

9. Agca CA, Tuzcu M, Gencoglu H, Akdemir F, Ali S, Sahin K and Kucuk O: Lycopene counteracts the hepatic response to 7,12-dimethylbenz[a]anthracene by altering the expression of Bax, Bcl-2, caspases and oxidative stress biomarkers. Pharm Biol 50: 1513-1518, 2012.

10. Marcotorchino J, Romier B, Gouranton E, Riollet C, Gleize B, Malezet-Desmoulins C and Landrier JF: Lycopene attenuates LPS-induced TNF- $\alpha$ secretion in macrophages and inflammatory markers in adipocytes exposed to macrophage-conditioned media. Mol Nutr Food Res 56: 725-732, 2012.

11. Trejo-Solís C, Pedraza-Chaverrí J, Torres-Ramos M, Jiménez-Farfán D, Cruz Salgado A, Serrano-García N, Osorio-Rico L and Sotelo J: Multiple molecular and cellular mechanisms of action of lycopene in cancer inhibition. Evid Based Complement Alternat Med 2013: 705121, 2013.

12. Karppi J, Laukkanen JA, Sivenius J, Ronkainen K and Kurl S: Serum lycopene decreases the risk of stroke in men: A population-based follow-up study. Neurology 79: 1540-1547, 2012. 
13. Hsiao G, Fong TH, Tzu NH, Lin KH, Chou DS and Sheu JR: A potent antioxidant, lycopene, affords neuroprotection against microglia activation and focal cerebral ischemia in rats. In Vivo 18: 351-356, 2004

14. Fujita K, Yoshimoto N, Kato T, Imada H, Matsumoto G, Inakuma T, Nagata $\mathrm{Y}$ and Miyachi E: Lycopene inhibits ischemia/reperfusion-induced neuronal apoptosis in gerbil hippocampal tissue. Neurochem Res 38: 461-469, 2013.

15. Prakash A and Kumar A: Lycopene protects against memory impairment and mito-oxidative damage induced by colchicine in rats: An evidence of nitric oxide signaling. Eur J Pharmacol 721: 373-381, 2013.

16. Kaur H, Chauhan S and Sandhir R: Protective effect of lycopene on oxidative stress and cognitive decline in rotenone induced model of Parkinson's disease. Neurochem Res 36: 1435-1443, 2011.

17. $\mathrm{Yi} \mathrm{F}, \mathrm{He} \mathrm{X}$ and Wang $\mathrm{D}$ : Lycopene protects against MPP(+)-induced cytotoxicity by maintaining mitochondrial function in SH-SY5Y cells. Neurochem Res 38: 1747-1757, 2013.

18. Qu M, Nan X, Gao Z, Guo B, Liu B and Chen Z: Protective effects of lycopene against methylmercury-induced neurotoxicity in cultured rat cerebellar granule neurons. Brain Res 1540: 92-102, 2013.

19. Qu M, Li L, Chen C, Li M, Pei L, Chu F, Yang J, Yu Z, Wang D and Zhou Z: Protective effects of lycopene against amyloid $\beta$-induced neurotoxicity in cultured rat cortical neurons. Neurosci Lett 505 286-290, 2011.

20. Qu M, Zhou Z, Chen C, Li M, Pei L, Chu F, Yang J, Wang Y, Li L, Liu C, et al: Lycopene protects against trimethyltin-induced neurotoxicity in primary cultured rat hippocampal neurons by inhibiting the mitochondrial apoptotic pathway. Neurochem Int 59: 1095-1103, 2011

21. di Matteo V, Pierucci M, Di Giovanni G, Dragani LK, Murzilli S, Poggi A and Esposito E: Intake of tomato-enriched diet protects from 6-hydroxydopamine-induced degeneration of rat nigral dopaminergic neurons. J Neural Transm Suppl: 333-341, 2009

22. Di Mascio P, Kaiser S and Sies H: Lycopene as the most efficient biological carotenoid singlet oxygen quencher. Arch Biochem Biophys 274: 532-538, 1989.

23. Alberio T, Bondi H, Colombo F, Alloggio I, Pieroni L, Urbani A and Fasano M: Mitochondrial proteomics investigation of a cellular model of impaired dopamine homeostasis, an early step in Parkinson's disease pathogenesis. Mol Biosyst 10: 1332-1344, 2014

24. Liang J, Yu Y, Wang B, Lu B, Zhang J, Zhang H and Ge P: Ginsenoside $\mathrm{Rb} 1$ attenuates oxygen-glucose deprivation-induced apoptosis in SH-SY5Y cells via protection of mitochondria and inhibition of AIF and cytochrome c release. Molecules 18 : 12777-12792, 2013.

25. Han DY,DiXJ,Fu YL and Mu TW: Combining valosin-containing protein (VCP) inhibition and suberanilohydroxamic acid (SAHA) treatment additively enhances the folding, trafficking and function of epilepsy-associated $\gamma$-aminobutyric acid, type A (GABAA) receptors. J Biol Chem 290: 325-337, 2015.

26. Watkins SC and Cullen MJ: A qualitative and quantitative study of the ultrastructure of regenerating muscle fibres in Duchenne muscular dystrophy and polymyositis. J Neurol Sci 82: 181-192, 1987.

27. Kwon SH, Kim JA, Hong SI, Jung YH, Kim HC, Lee SY and Jang CG: Loganin protects against hydrogen peroxide-induced apoptosis by inhibiting phosphorylation of JNK, p38 and ERK 1/2 MAPKs in SH-SY5Y cells. Neurochem Int 58: 533-541, 2011.

28. James D, Parone PA, Terradillos O, Lucken-Ardjomande S, Montessuit S and Martinou JC: Mechanisms of mitochondrial outer membrane permeabilization. Novartis Found Symp 287: 170-176, 2007

29. Nakka VP, Gusain A, Mehta SL and Raghubir R: Molecular mechanisms of apoptosis in cerebral ischemia: Multiple neuroprotective opportunities. Mol Neurobiol 37: 7-38, 2008.

30. Springer JE: Apoptotic cell death following traumatic injury to the central nervous system. J Biochem Mol Biol 35: 94-105, 2002

31. Alves da Costa C and Checler F: Apoptosis in Parkinson's disease: Is p53 the missing link between genetic and sporadic Parkinsonism? Cell Signal 23: 963-968, 2011.

32. Zhang L, Yu H, Sun Y, Lin X, Chen B, Tan C, Cao G and Wang Z: Protective effects of salidroside on hydrogen peroxide-induced apoptosis in SH-SY5Y human neuroblastoma cells. Eur J Pharmacol 564: 18-25, 2007.
33. Kim SY, Seo M, Kim Y, Lee YI, Oh JM, Cho EA, Kang JS and Juhnn YS: Stimulatory heterotrimeric GTP-binding protein inhibits hydrogen peroxide-induced apoptosis by repressing BAK induction in SH-SY5Y human neuroblastoma cells. J Biol Chem 283: 1350-1361, 2008.

34. Yue R, Hu H, Yiu KH, Luo T, Zhou Z, Xu L, Zhang S, Li K and Yu Z: Lycopene protects against hypoxia/reoxygenation-induced apoptosis by preventing mitochondrial dysfunction in primary neonatal mouse cardiomyocytes. PLoS One 7: e50778, 2012.

35. Méndez-Armenta M, Nava-Ruíz C, Juárez-Rebollar D, Rodríguez-Martínez E and Gómez PY: Oxidative stress associated with neuronal apoptosis in experimental models of epilepsy. Oxid Med Cell Longev 2014: 293689, 2014.

36. Sugawara $\mathrm{T}$ and Chan PH: Reactive oxygen radicals and pathogenesis of neuronal death after cerebral ischemia. Antioxid Redox Signal 5: 597-607, 2003

37. Uttara B, Singh AV,Zamboni P and Mahajan RT: Oxidative stress and neurodegenerative diseases: A review of upstream and downstream antioxidant therapeutic options. Curr Neuropharmacol 7: 65-74, 2009.

38. Tang X, Yang X, Peng Y and Lin J: Protective effects of lycopene against $\mathrm{H} 2 \mathrm{O} 2$-induced oxidative injury and apoptosis in human endothelial cells. Cardiovasc Drugs Ther 23: 439-448, 2009.

39. Palozza P, Simone R, Catalano A, Boninsegna A, Böhm V, Fröhlich K, Mele MC, Monego G and Ranelletti FO: Lycopene prevents 7-ketocholesterol-induced oxidative stress, cell cycle arrest and apoptosis in human macrophages. J Nutr Biochem 21: 34-46, 2010

40. Srinivasan M, Devipriya N, Kalpana KB and Menon VP: Lycopene: An antioxidant and radioprotector against gamma-radiation-induced cellular damages in cultured human lymphocytes. Toxicology 262: 43-49, 2009.

41. Sugawara T, Fujimura M, Noshita N, Kim GW, Saito A,Hayashi T, Narasimhan P, Maier CM and Chan PH: Neuronal death/survival signaling pathways in cerebral ischemia. NeuroRx 1: 17-25, 2004

42. Sandhir R, Mehrotra A and Kamboj SS: Lycopene prevents 3-nitropropionic acid-induced mitochondrial oxidative stress and dysfunctions in nervous system. Neurochem Int 57: 579-587, 2010.

43. Harris MH and Thompson CB: The role of the Bcl-2 family in the regulation of outer mitochondrial membrane permeability. Cell Death Differ 7: 1182-1191, 2000.

44. Javadov S, Karmazyn M and Escobales N: Mitochondrial permeability transition pore opening as a promising therapeutic target in cardiac diseases. J Pharmacol Exp Ther 330: 670-678, 2009.

45. He Q, Zhou W, Xiong C, Tan G and Chen M: Lycopene attenuates inflammation and apoptosis in post-myocardial infarction remodeling by inhibiting the nuclear factor- $\kappa \mathrm{B}$ signaling pathway. Mol Med Rep 11: 374-378, 2015.

46. Lv JC, Wang G, Pan SH, Bai XW and Sun B: Lycopene protects pancreatic acinar cells against severe acute pancreatitis by abating the oxidative stress through JNK pathway. Free Radic Res 49: 151-163, 2015

47. Gao Y, Jia P, Shu W and Jia D: The protective effect of lycopene on hypoxia/reoxygenation-induced endoplasmic reticulum stress in H9C2 cardiomyocytes. Eur J Pharmacol 774: 71-79, 2016.

48. Chen F, Sun ZW, Ye LF, Fu GS, Mou Y and Hu SJ: Lycopene protects against apoptosis in hypoxia/reoxygenation-induced H9C2 myocardioblast cells through increased autophagy. Mol Med Rep 11: 1358-1365, 2015.

49. Polster BM: AIF, reactive oxygen species and neurodegeneration: A ‘complex' problem. Neurochem Int 62: 695-702, 2013.

50. Ba XH, Cai LP and Han W: Effect of cilostazol pretreatment on the PARP/AIF-mediated apoptotic pathway in rat cerebral ischemia-reperfusion models. Exp Ther Med 7: 1209-1214, 2014.

51. Yang X, Wang S, Lin Y, Han Y, Qiu X, Zhao X, Cao L, Wang X and Chi Z: Poly (ADP-ribose) polymerase inhibition protects epileptic hippocampal neurons from apoptosis via suppressing Akt-mediated apoptosis-inducing factor translocation in vitro. Neuroscience 231: 353-362, 2013.

52. Huang C, Lin Y, Su H and Ye D: Forsythiaside protects against hydrogen peroxide-induced oxidative stress and apoptosis in PC12 cell. Neurochem Res 40: 27-35, 2015.

53. Hu G, Wu Z, Yang F, Zhao H, Liu X, Deng Y, Shi M and Zhao G: Ginsenoside Rd blocks AIF mitochondrio-nuclear translocation and NF- $\mathrm{BB}$ nuclear accumulation by inhibiting poly (ADP-ribose) polymerase-1 after focal cerebral ischemia in rats. Neurol Sci 34: 2101-2106, 2013. 